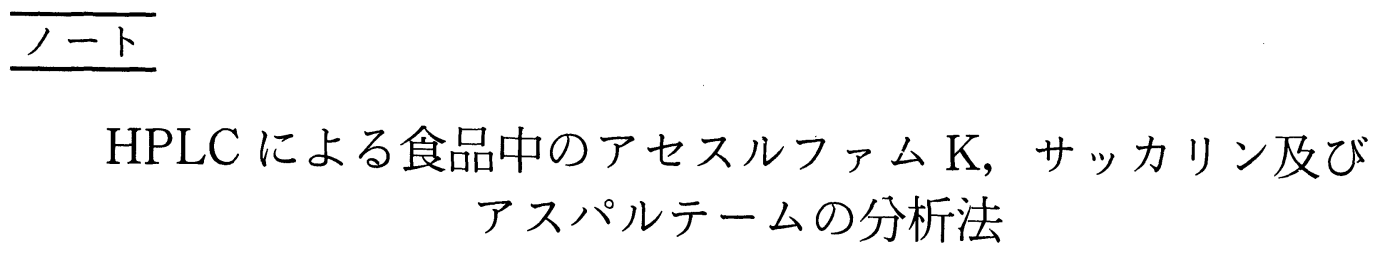

(平成 7 年 6 月 24 日受理)

$\begin{array}{lll}\text { 守安貴子* } & \text { 中里光男* } & \text { 小林千種* } \\ \text { 菊地洋子* } & \text { 早野公美* } & \text { 田村行弘* }\end{array}$

\title{
Determination of Acesulfame K, Saccharin and Aspartame in Various Foods by HPLC
}

\author{
Takako Moriyasu, Mitsuo Nakazato, Chigusa Kobayashi, Yoko Kikuchi, \\ Kumi Hayano and Yukihiro Tamura \\ (The Tokyo Metropolitan Research Laboratory of Public Health: \\ 3-24-1, Hyakunin-cho, Shinjuku-ku, Tokyo 169, Japan)
}

\begin{abstract}
Method for the determination of acesulfame $\mathrm{K}(\mathrm{AK})$, saccharin (SA) and aspartame (APM) in various foods was investigated. Chopped or homogenized samples were packed with 0.01 $N$ hydrochloric acid containing $10 \%$ sodium chloride into cellulose tubing and dialyzed against $0.01 \mathrm{~N}$ hydrochloric acid for $24 \sim 48$ hours. For the detection of $\mathrm{AK}$ and SA, the dialyzate was analysed directly by HPLC on a Cosmosil $5 \mathrm{NH}_{2}$ column using a mobile phase of methanol-1\% phosphoric acid $(6: 4)$ with detection at $230 \mathrm{~nm}$. For APM, the dialyzate was passed through a Sep-pak Vac C18 cartridge. The cartridge was washed with water and a mixture of methanol-water $(2: 8)$. APM was eluted with a mixture of methanol-1\% phosphoric acid $(3: 7)$. It was separated on a Cosmosil $5 \mathrm{C} 18$-AR column using a mobile phase of methanol-0.02 $M$ phosphate buffer $\mathrm{pH} 4.0(1: 3)$ with detection at $210 \mathrm{~nm}$.

The recoveries of AK, SA and APM added to various foods were $94.3 \sim 100.4 \%, 80.4 \sim$ $99.6 \%$ and $90.8 \sim 101.7 \%$, respectively. The detection limits of AK and APM were $10 \mu \mathrm{g} / \mathrm{g}$ and that of SA was $5 \mu \mathrm{g} / \mathrm{g}$.
\end{abstract}

(Received June 24, 1995)

Key words: アセスルファム K acesulfame K; サッカリン saccharin; アスパルテーム aspartame; 高速液体クロマトグラフィーHPLC; アミノプロピルカラム aminopropyl column; ODS $\left(\mathrm{C}_{18}\right)$ カラム ODS $\left(\mathrm{C}_{18}\right)$ column; 透析法 dialysis; 固相抽出 solid-phase extraction

\section{緒言}

著者らは先に, 我が国では不許可添加物であるアセス ルファム $\mathrm{K}(\mathrm{AK})^{1), 2)}$ 之許可添加物であるサッカリン (SA) 及びアスパルテーム (APM) の 3 種の合成甘味料の 分析法を報告しだ). しかし，この方法はクリーンアッ プの際に，固相抽出用のカートリッジを 1 検体につき 3 本使用することから, 簡便性及び経済性の点から改良の 余地があった。 また，その後，種々の市販食品にこの方

* 東京都立衛生研究所：テ169 東京都新宿区百人町 3-24-1
法を適用したところ，ビスケット，さきいかなどで $\mathrm{AK}$ 及び SA の回収率が低いあのがあった。そこでこれらの 点を改善するとともに，簡便で精度が良く，広範囲な食 品に適用できる分析法について検討したので，その結果 を報告する。

\section{実験方法}

1. 試薬

1) AK及び SA 混合標準原液：AK（純度 $99.1 \%$, 和光純薬工業(株)製, 生化学用) 約 $100 \mathrm{mg}$ 及びサッ カリンナトリウム (二水和物, 特級, 和光純薬工業(株) 
製) 約 $118 \mathrm{mg}$ を精ひょうし, 水に溶解して全量を $100 \mathrm{ml}$ とした.

2) APM 標準原液：APM（純度 $98.0 \%$ 以上，和光 純薬工業(株)製, 食品添加物試験用) 約 $100 \mathrm{mg}$ を精 ひょうし，水に溶解して全量を $100 \mathrm{ml}$ とした.

3）透析内液用溶液：塩化ナトリウム $100 \mathrm{~g}$ を 0.01 $N$ 塩酸に溶解して $1,000 \mathrm{ml}$ とした.

4) 透析外液用溶液： $0.01 N$ 塩酸

5）透析膜：透析用セルロースチューブ 30/32（平面 幅 $40 \mathrm{~mm}$, 直径 $25 \mathrm{~mm}$, 膜厚 $0.0305 \mathrm{~mm}$, Viskase sales 社製)

6) 前処理用カートリッジカラム：Sep-pak Vac C18（逆相系, 充てん量 1,000 mg, Millipore 社製)を 用いた。 カートリッジは使用前に $\mathrm{MeOH} 5 \mathrm{ml}$ 及び水 5 $\mathrm{ml}$ で順次洗浄した.

7) $1 \%$ リン酸： $85 \%$ リン酸 $11.8 \mathrm{~g}$ に水を加え, $1,000 \mathrm{ml}$ とした.

8) $\mathrm{MeOH}$ : 高速液体クロマトグラフ用を用いた.

9） $0.02 M$ リン酸緩衝液： $0.2 M$ リン酸水素二ナト リウム $500 \mathrm{ml}$ と $0.2 \mathrm{M}$ リン酸 $470 \mathrm{ml}$ を混和，これを 用時, 10 倍希釈して約 $\mathrm{pH} 4.0$ の緩衝液を作製した。

10）その他の試薬は市販特級品を用いた.

\section{2. 装}

高速液体クロマトグラフ：日本分光工業 (株)製, 880-PU 型ポンプ, 同 875-UV 型検出器, 同 860-CO 型 カラム恒温槽, (株)島津製作所製 C-R6A 型デー夕処理 装置及びレオダイン社製 7125 インジェクターにより構 成した。

3. HPLC 条件

1) $\mathrm{AK}$ 及び $\mathrm{SA}$

カラム: Cosmosil $5 \mathrm{NH}_{2}(5 \mu \mathrm{m}, 250 \mathrm{~mm} \times 4.6 \mathrm{~mm}$ i.d.); 移動相: $\mathrm{MeOH}-1 \%$ リ酸 (6 : 4); 流速: $1.5 \mathrm{ml}$ / $\mathrm{min}$; 検出波長： $230 \mathrm{~nm}$; カラム温度： $40^{\circ}$; 注入量： $10 \mu 1$

\section{2) APM}

カラム: Cosmosil 5C18-AR $(5 \mu \mathrm{m}, 250 \mathrm{~mm} \times 4.6$ $\mathrm{mm}$ i.d.); 移動相: $\mathrm{MeOH}-0.02 M$ リン酸緩衝液 $\mathrm{pH} 4.0$ (1:3); 流速: $1.0 \mathrm{ml} / \mathrm{min}$; 検出波長： $210 \mathrm{~nm}$; カラム 温度： $40^{\circ}$; 注入量： $20 \mu 1$

\section{4. 試験溶液の調製}

1) 透析：固体試料は細切又はホモジナイズした後, 液体試料はそのまま各々 $20 \mathrm{~g}$ を正確に量り，これを透 析内液用溶液で透析膜に充てんし, 内容物をよく混和し て上端を密封した。これをメスシリンダー中に入れた 後, 透析外液用溶液で全量を $200 \mathrm{ml}$ とし, 時々摇り動 かしながら室温で 24 時間, 乳製品, 穀物調製品及び魚 介乾燥品などの一部の食品については 48 時間透析を 行った.
2） HPLC 用試験溶液の調製

$\mathrm{AK}$ 及び SA：透析外液を $0.45 \mu \mathrm{m}$ のメンブランフィ ルターでろ過し, 万液を AK 及び SA 用の HPLC 用試 験溶液とした。

APM: 透析外液 $5 \mathrm{ml}$ を Sep-pak Vac C 18 カート リッジに毎分 3〜 $4 \mathrm{ml}$ の速度で負荷した。これを水 5 $\mathrm{ml}$, 次いで $\mathrm{MeOH}$-水 $(2: 8)$ 混液 $10 \mathrm{ml}$ で洗浄した後, $\mathrm{MeOH}-1 \%$ リン酸 (3:7) 混液で溶出し, 全量を $10 \mathrm{ml}$ としたものを APM 用の HPLC 用試験溶液とした。

\section{5. 検量線の作成}

1) $\mathrm{AK}$ 及び $\mathrm{SA}$ ：混合標準原液を水で希釈し，2, 5, 10,50 及び $100 \mu \mathrm{g} / \mathrm{ml}$ の混合標準溶液を調製し, その $10 \mu 1$ を高速液体クロマトグラフに付し, ピーク面積法 により検量線を作成した。

2) APM：：標準原液を水で希釈し， AK 及び SA と 同様に検量線を作成した。ただし，高速液体クロマトグ ラフへの注入量は $20 \mu 1$ とした。

\section{結果及び考察}

\section{1. 透析}

前報 ${ }^{3)}$ に従い，種々の試料について検查を行ったとこ ろ，原材料に鶏卵や脱脂粉乳などが用いられたビスケッ トなどの穀類調製品及びさきいかなどの魚介乾燥品の回 収率が， AK で $60 \%$ 程度，SA で $50 \%$ 程度と良くな かった。一般に, タンパク質の塩基性基が酸性溶液中で イオン化し, 低分子陰イオンと結合することは良く知ら れており ${ }^{4)}$ こうした食品の回収率が低かったのあ，食 品中の夕ンパク質と, 解離した AK 及び SA が結合し, 透析されにくくなるためと考えられる. 一方, 溶液中に 共存する陰イオンは，AK及び SA と競合し，この結合 を阻害する作用がある.リン酸溶液で透析した場合, 陰 イオンとしてリン酸イオンが存在するが，陰イオン交換 の SAX カートリッジに保持された AK及び SA がリン 酸溶液では溶出しないことから ${ }^{3)}$, リン酸イオンは $\mathrm{AK}$ 及び SA と塩基性基との結合を阻害する作用が極めて弱 いものと思われる5). 従って, この結合を防ぐために は, 透析液の $\mathrm{pH}$ を中性付近とし, 塩基性基のイオン化

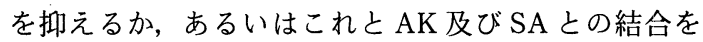
妨げるような, 塩基性基に対してより選択性の高いイオ ンを添加する方法が考えられる。 しかし，透析液を中性 付近にした場合, APM は pH 6 以上では不安定であ

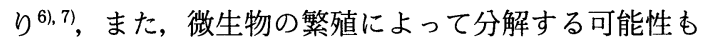
あることから，回収率が低下することが予想される。 そ こで, 透析液には APM の分解を防止するために希薄な 酸性溶液を用い, 更に結合を阻害するイオンを添加する こととした。一般に塩基性基との選択性が比較的大きい 塩化物イオン ${ }^{5)}$ は, 塩基性基と酸性物質との結合を阻害 するのによく用いられる，また，合成甘味料の透析に塩 酸溶液之塩化ナトリウムとの組み合わせが用いられるこ とから ${ }^{8199}$, 本法においても透析液に $0.01 \mathrm{~N}$ の塩酸を用 
(A)

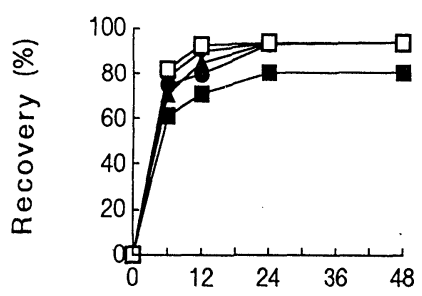

(B)

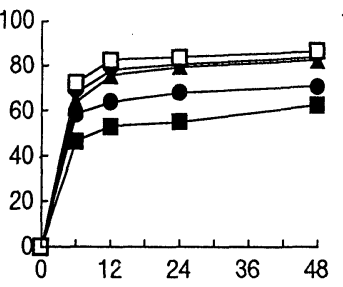

(C)

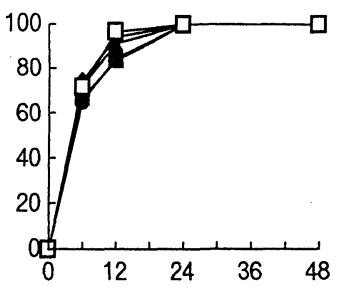

Time(hr.)

Fig. 1. Effect of concentration of sodium chloride in dialyzing solution on recoveries of the sweeteners

(A) acesulfame K, (B) saccharin, (C) aspartame

$\square$ - $0 \%, \bullet-\bullet: 2.5 \%, \mathbf{\Delta}-\mathbf{\Delta}: 5.0 \%, \diamond \rightarrow: 7.5 \%, \square-\square: 10 \% \mathrm{NaCl}$

The sample was biscuit added sweeteners.

いることとし，添加する塩化ナトリウムの濃度について 検討を行った，試料には，前報)で AK 及び SA の回収 率が約 $60 \%$ と良くなかったビスケットを用い，これに 3 種の甘味料を添加し, 透析内液として 0, 2.5, 5, 7.5 及び $10 \%$ の塩化ナトリウムを含有する $0.01 N$ 塩酸約 $20 \mathrm{ml}$ を用いて透析し, 3 種の甘味料の回収率を経時的 に測定した。結果は Fig. 1 に示したように, APM は 塩化ナトリウムの添加の有無に関わらず，24 時間でほ ぼ全量が透析された．AK は塩化ナトリウム無透加の場 合, 48 時間の透析でも $80 \%$ 程度の回収率しか得られ なかったが, 塩化ナトリウム $2.5 \%$ 以上添加ではいず れ屯 48 時間で $94 \%$ 以上の回収率が得られた。 また, $\mathrm{SA}$ は 48 時間の透析で, 塩化ナトリウム無添加では約 60\% であったが, 塩化ナトリウムの添加量が増加する に従い，回収率は徐々に上昇し，10\%添加では $85 \%$ の 回収率が得られた。しかし，それ以上は塩化ナトリウム の添加量を増やしてあ回収率の上昇は認められなかっ た.これらの結果から，透析内液には $10 \%$ 塩化ナトリ ウムを含有する $0.01 N$ 塩酸を用いることとした．また， 透析時間については, 漬物, ジュース, 液状調味料類, ジャムなど, 大半の食品については 24 時間の透析で十 分であったが、ヨーグルトなどの乳製品, ビスケットな ぞの穀物調製品及びさきいかなどの魚介乾燥品では, 良 好な回収率を得るためには 48 時間透析する必要があっ た.

\section{AK 及び SA の HPLC 条件}

衛生試験法・注解10) に収載されている SA の HPLC は, カラムにアミノプロピル基を結合させたもの $\left(\mathrm{NH}_{2}\right.$ カラム) を, 移動相に $1 \%$ リン酸- $\mathrm{MeOH}$ を用いたイオ ン交換モードの HPLC 条件を採用している.この場合, 透析液をフィルターろ過したものを HPLC 分析用の試 験溶液としており，簡便である，AK あ SA と同様な強 酸性物質であり, 強陰イオン交換カートリッジ内での挙

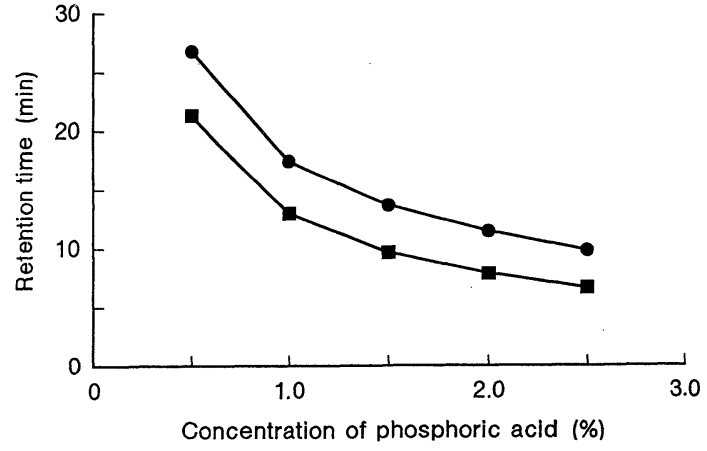

Fig. 2. Effect of phosphoric acid concentration in the mobile phase on the retention time of acesulfame $\mathrm{K}$ and saccharin

- - acesulfame K, $\square-$ : saccharin HPLC conditions; column: Cosmosil $5 \mathrm{NH}_{2}$ (4.6 mm i.d. $\left.\times 250 \mathrm{~mm}\right)$, mobile phase: $\mathrm{MeOH}-$ phosphoric acid $(6: 4)$, flow rate: $1.5 \mathrm{ml} / \mathrm{min}$, column temperature: $40^{\circ} \mathrm{C}$, detection: UV $230 \mathrm{~nm}$

動がほぼ同じであることから ${ }^{3)}, \mathrm{NH}_{2}$ カラムを用いたイ オン交換モードの HPLCでSA との同時分析ができる あのと考えられる。 そこで $\mathrm{NH}_{2}$ カラムを用い, 両者を 分離するための移動相条件について検討を行うこととし た。

移動相条件は衛生試験法・注解10) に準拠し, リン酸 溶液と $\mathrm{MeOH}$ との混液を用いて検討を行った。 まず, リン酸溶液と $\mathrm{MeOH}$ の混合比を $4: 6$ とし, このリン酸 溶液の濃度を $0.5 \sim 2.5 \%$ に変化させた際の $\mathrm{AK}$ 及び SA の分離について調べた. 結果は Fig. 2 に示すよう にいずれの濃度においてす AK と SA の分離は良好で あった. また, リン酸濃度が高くなるに従い, 両者の保 持時間は早くなる傾向がみられたが, 夾雑物との分離, 


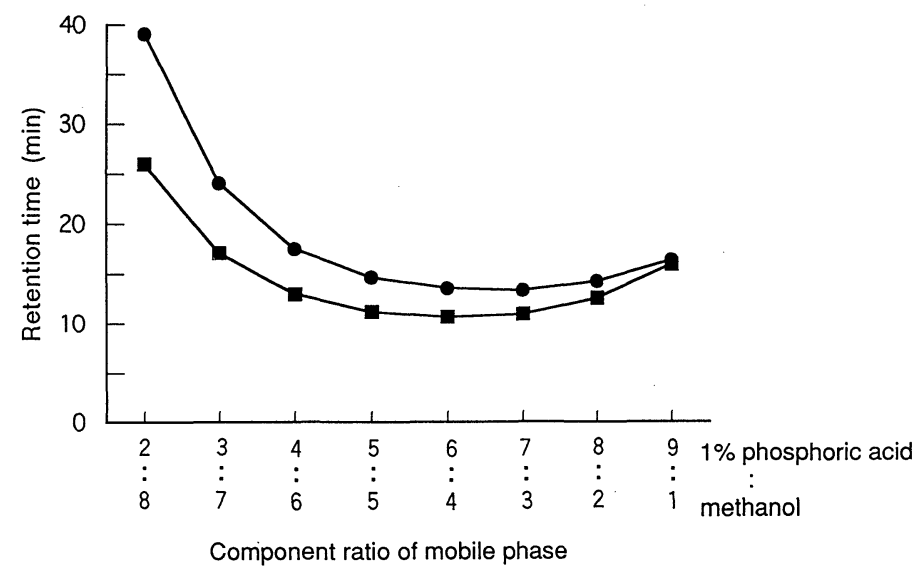

Fig. 3. Effect of the ratio of methanol and $1 \%$ phosphoric acid of the mobile phase on the retention time of acesulfame $\mathrm{K}$ and saccharin

- acesulfame K, D- $\mathbf{D}$ : saccharin

HPLC conditions; column: Cosmosil $5 \mathrm{NH}_{2}(4.6 \mathrm{~mm}$ i.d. $\times 250 \mathrm{~mm})$, mobile phase: $\mathrm{MeOH}-1 \%$ phosphoric acid, flow rate: $1.5 \mathrm{ml} / \mathrm{min}$, column temperature: $40^{\circ} \mathrm{C}$, detection: UV $230 \mathrm{~nm}$

Table 1. Recoveries of Sweeteners from Foods

\begin{tabular}{lcrrr}
\hline \hline \multirow{2}{*}{ Sample } & \multirow{2}{*}{$\begin{array}{c}\text { Dialyzing time } \\
\text { (hr) }\end{array}$} & Acesulfame K & Saccharin & Aspartame \\
\cline { 3 - 5 } & 24 & $97.6 \pm 1.0$ & $95.6 \pm 0.8$ & $99.0 \pm 2.8$ \\
Apple juice & 24 & $100.4 \pm 1.3$ & $99.6 \pm 1.9$ & $101.7 \pm 2.7$ \\
Soy sauce & 24 & $98.8 \pm 1.8$ & $98.8 \pm 2.4$ & $90.8 \pm 1.3$ \\
Wercester sauce & 24 & $98.1 \pm 1.3$ & $95.7 \pm 1.2$ & $91.8 \pm 1.7$ \\
Strawberry jam & 24 & $98.1 \pm 1.5$ & $95.5 \pm 1.2$ & $96.8 \pm 2.2$ \\
Canned peach & 24 & $96.7 \pm 1.3$ & $95.7 \pm 0.9$ & $99.5 \pm 2.5$ \\
Pickles with vinegar & 24 & $98.0 \pm 1.9$ & $96.3 \pm 1.9$ & $97.8 \pm 0.6$ \\
Takuan-zuke & 48 & $94.9 \pm 1.4$ & $89.7 \pm 1.1$ & $94.0 \pm 3.8$ \\
Yogurt & 48 & $94.3 \pm 0.8$ & $85.1 \pm 1.5$ & $98.2 \pm 5.0$ \\
Biscuit & 48 & $95.3 \pm 2.2$ & $80.4 \pm 1.6$ & $90.8 \pm 2.5$ \\
Dried cuttlefish & & & & \\
\hline
\end{tabular}

* Data are mean \pm SD. $(n=4)$

分析時間及び高速液体クロマトグラフポンプヘの影響を 考え, 移動相に用いるリン酸濃度は $1 \%$ とした. 次に $1 \%$ リン酸と $\mathrm{MeOH}$ の混合比について検討を行った. 結果は Fig. 3 に示すように，1\%リン酸の比率が高くな るに従って $\mathrm{AK}$ とA の分離は悪くなった. また, 両 者の保持時間は $1 \%$ リン酸- $\mathrm{MeOH}$ の混合比が $2: 8$ か ら 6:4 までは 1\%リン酸の比率が増加するに従って早 くなるが, 更に $1 \%$ リン酸の比率が高くなると逆に遅 くなる傾向がみられた.これらの結果から, 分析条件と

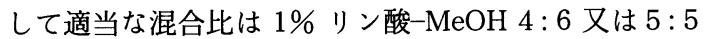
であることが分かった. しかし, 夾雑物との分離の点で $4: 6$ の方が $5: 5$ よりあ良好であったため, 移動相の $1 \%$ リン酸- $\mathrm{MeOH}$ の混合比は $4: 6$ とした.

\section{APM のクリーンアップ条件及び HPLC 条件}

1) クリーンアップ条件：強陽イオン交換カートリッ ジを用いた APM のクリーンアップでは, 負荷する試料 溶液の $\mathrm{pH}$ が 3 以上では，塩化ナトリウムの影響を強く 受けることから，その影響を除くために試料溶液の $\mathrm{pH}$ を 2 以下とする必要がある ${ }^{3)}$. 従って, 本法の透析液の 組成では, $\mathrm{pH}$ 調整が不可欠となる. 一方, 寺田ら ${ }^{11)}$ は APM が pH 2〜6の間で Sep-pak C18 カートリッジに 保持されると報告している. 従って，このカートリッジ を用いれば $\mathrm{pH}$ 調整を行うことなく, 簡便にクリーン アップできるものと考えられた. そこで, Sep-pak Vac $\mathrm{C} 18$ (充てん量 $1,000 \mathrm{mg}$ ) を用いて, 種々の試料の透 析液について, pH 調整せずに, そのまま負荷したとこ ろ, いずれの試料においても APM の保持が可能であっ 


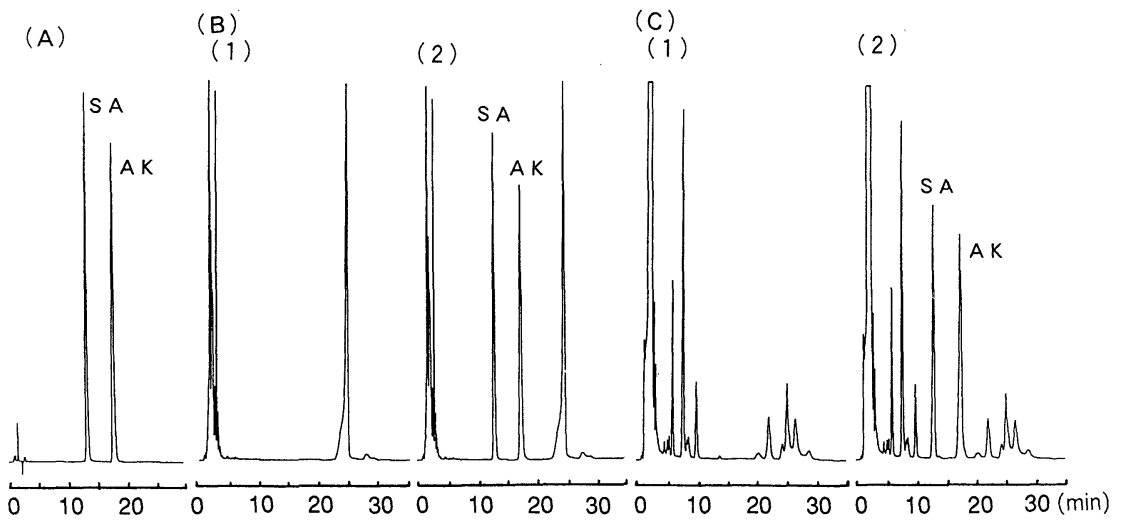

Fig. 4. HPLC chromatograms of standard solution of acesulfame $K$ and saccharin (A), extract of Takuan-zuke (B), and extract of dried cuttlefish (C)

(1) control, (2) sweeteners added $(200 \mu \mathrm{g} / \mathrm{g})$

HPLC conditions; column: Cosmosil $5 \mathrm{NH}_{2}(4.6 \mathrm{~mm}$ i.d. $\times 250 \mathrm{~mm})$, mobile phase: $\mathrm{MeOH}-1 \%$ phosphoric acid $(6: 4)$, flow rate: $1.5 \mathrm{ml} / \mathrm{min}$, column temperature: $40^{\circ} \mathrm{C}$, detection: UV $230 \mathrm{~nm}$, injection volume: $10 \mu 1$

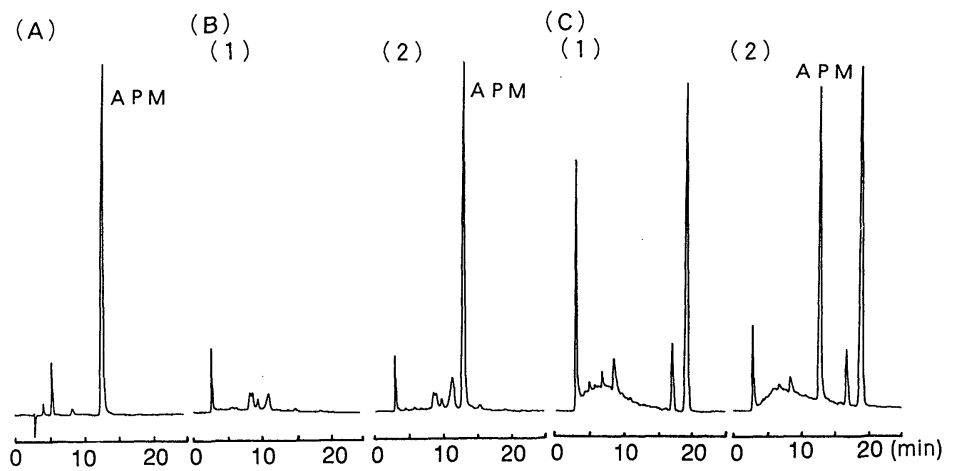

Fig. 5. HPLC chromatograms of standard solution of aspartame (A), extract of Takuan-zuke (B), and extract of dried cuttlefish (C)

(1) control, (2) sweeteners added $(200 \mu \mathrm{g} / \mathrm{g})$

HPLC conditions; column: Cosmosil 5C18-AR $(4.6 \mathrm{~mm}$ i.d. $\times 250 \mathrm{~mm})$, mobile phase: $\mathrm{MeOH}-0.02 \mathrm{M}$ phosphate buffer $\mathrm{pH} 4.0$ (1:3), flow rate: $1.0 \mathrm{ml} / \mathrm{min}$, column temperature: $40^{\circ} \mathrm{C}$, detection: UV $210 \mathrm{~nm}$, injection volume: $20 \mu \mathrm{l}$

た.しかし，寺田ら ${ }^{11)}$ の方法では試料負荷後の洗浄を 水のみで行っており, 夾雑物の多い試料ではクリーン アップ不足となる傾向があった. そこで，洗浄液とし て, 洗浄効果の高い $\mathrm{MeOH}$-水を加え, その比率及び液 量について検討した. その結果, 水 $5 \mathrm{ml}$ で洗浄した 後, 更に $\mathrm{MeOH}$-水 $(2: 8)$ 混液 $10 \mathrm{ml}$ で洗浄したとき, APM が溶出することなく, 夾雑物の大幅な除去が可能 であった. しかし，この $\mathrm{MeOH}$-水混液で過剰に洗浄す ると, 洗浄液量 $15 \sim 35 \mathrm{ml}$ 中に $\mathrm{APM}$ が溶出されるこ とから, 洗浄は正確に $10 \mathrm{ml}$ で行う必要があった.

次に, 溶出液について $\mathrm{MeOH}$-水系を用いて検討し た. カラム内に残っている夾雑物の溶出を防ぐために
は, $\mathrm{MeOH}$ の比率が低い方が，また，溶出液量は少な い方が好ましい. そこで, 溶出液の $\mathrm{pH}$ を下げて APM のイオン化を促進し，より $\mathrm{MeOH}$ の比率が少ない条件 で溶出させるために, 水の代わりに $1 \%$ リン酸を用い ることとした. その結果, $\mathrm{MeOH}-1 \%$ リ酸の比率は $3: 7$ が適当であり, また, 溶出液量は $8 \mathrm{ml}$ で APM の ほぼ全量が溶出したため, $10 \mathrm{ml}$ とした.

\section{2) HPLC 条件}

APMの分析は, 寺田ら ${ }^{11)}$ の HPLC 条件に準じて 行った.すなわち, カラムには Cosmosil 5C 18-AR を，移動相には $\mathrm{MeOH}-0.02 M$ リン酸緩衝液 ( $\mathrm{pH} \mathrm{4.0)}$ $(1: 3)$ 混液を用いて, 種々の試料について分析したとこ 
ろ, いずれも夾雑物との分離が良く, 良好なクロマトグ ラムが得られた。

\section{4. 添加回収実験}

$\mathrm{AK}, \mathrm{SA}$ 及び APM が検出されないことを確認したり んごジュース, しょう油, ソース, いちごジャム, 桃の 缶詰, ヨーグルト, 酢漬け, たくあん漬け, ビスケット 及びさきいかの 10 種の食品について, 添加回収実験を 行った. 液状食品はそのまま, 固形食品は細切後, 3 種 の甘味料をそれぞれ $200 \mu \mathrm{g} / \mathrm{g}$ になるように添加し， 6 時間放置した試料を本法に従って操作した。 回収率は Table 1 に示したように, AKが 94.3〜 100.4\%, SA が 80.4〜 99.6\%, APM が 90.8〜 101.7\%であった. AK及び APM についていずれの食品においても 90\% 以上の回収率が得られた. SAについてはヨーグ ルト，ビスケット及びさきいかで 80.4 89.7\% とやや 回収率が低い傾向がみられたが, 本法が 3 種の甘味料 の分析法であることを考慮すると, 実用上, 十分な回収 率が得られたと考える。

標準品と, たくあん漬け及びさきいかより得た試験溶 液の, AK 及び SA についてのクロマトグラムを Fig. 4 に, APM についてのクロマトグラムを Fig. 5 に示し た. いずれの甘味料についても夾雑物と分離ができ, 良 好なクロマトグラムが得られた。

また, 本法における検出限界は, 試料中濃度として, $\mathrm{AK}$ 及び APM で $10 \mu \mathrm{g} / \mathrm{g}, \mathrm{SA}$ で $5 \mu \mathrm{g} / \mathrm{g}$ であった.

\section{まとめ}

食品中の $\mathrm{AK}, \mathrm{SA}$ 及び APM の分析法について, 簡 便で精度む良く，経済性の高い試験法を作成した。

1. 試料中からの AK, SA 及び APM の抽出には透析 法を用い, 透析内液として 10\% 塩化ナトリウムを含有 する $0.01 N$ 塩酸を用いた.これにより，ビスケット， さきいかなど，前報で回収率の良くなかった試料につい て回収率を高めることができた。
2. $\mathrm{AK}$ 及び SA の HPLC 分析に $\mathrm{NH}_{2}$ カラムを用い ることにより，クリーンアップ操作をすることなく分析 することができ, 大幅に簡素化できた.

3. APM はクリーンアップに Sep-pak Vac C18 カートリッジを用い, 洗浄に $\mathrm{MeOH}$-水を用いることに より, $\mathrm{pH}$ 調整なしで夾雑物の大幅な除去が可能となっ た.

4. 本法における定量限界は試料中濃度として AK 及 び APM で $10 \mu \mathrm{g} / \mathrm{g}, \mathrm{SA}$ で $5 \mu \mathrm{g} / \mathrm{g}$ であった.

5. 10 種の食品に 3 種の甘味料を添加した際の回収 率は AK及び APM で $90 \%$ 以上， SA で $80 \%$ 以上で あった。

\section{文献}

1) Hough, C. A. M., Parker, K. J., Vlitos, A. J.: "Developments in Sweeteners - 1" p. 151 158 (1979) Applied Science Publishers Ltd., London.

2）香川輝彦：“世界の食品添加物” p. 60～64 (1994) 食品化 学新聞社.

3) 守安貴子, 斎藤和夫, 中里光男, 石川ふさ子, 藤沼賢司, 二島太一郎：衛生化学 37, 97 102 (1991).

4) 水島三一郎, 赤堀四郎編：“蛋白質化学 4” p. 31 45(1956) 共立出版.

5）久保博昭監修：“固相抽出法ハンドブック” p. 98〜104 (1986) ユニフレックス.

6) 西島基弘, 冠 政光, 高橋尚子, 上村 尚, 中里光男, 渡利優子，木村康夫：食衛誌. 17, 78〜84 (1976).

7） 中村圭寛：醸協. 86, 200 207 (1991).

8) 谷村顕雄, 藤井正美, 義平邦利, 伊藤誉志男, 城 照雄 監修: “食品中の食品添加物分析法解説書” p. 354 364 (1992) 講談社.

9) 中里光男, 斎藤和夫, 石川ふさ子, 藤沼賢司, 守安貴子, 二島太一郎：食衛誌. 34, 248 253 (1993).

10）日本薬学会編：“公衆衛生協議会資料” p. 12 13 (1994).

11）寺田久屋, 坂部美雄: 衛生化学 29, 394 399 (1983). 